\title{
Review of the Mimela species of the Dalat Plateau in southern Vietnam (Coleoptera, Scarabaeidae, Rutelinae)
}

\author{
With 75 figures
}

Artem M. Prokofiev ${ }^{1}$ and Carsten Zorn ${ }^{2}$

${ }^{1}$ A.N. Severtsov Institute for Ecology and Evolution, Russian Academy of Sciences, Leninsky prospect 33, 119071 Moscow, Russia

2 Rostocker Strasse 1a, 17179 Gnoien, Germany. - czorn70@hotmail.com

Published on 2016-12-20

\section{Summary}

Twelve species of Mimela are recorded from the Dalat Plateau in southern Vietnam of which ten are described as new to science. The majority of species appear to be endemics and have Sino-Himalayan relatives.

\section{Key words}

Coleoptera, Scarabaeoidea, Scarabaeidae, Rutelinae, Anomalini, Mimela, Vietnam, Dalat, new species, taxonomy, Oriental region

\section{Zusammenfassung}

Zwölf Arten der Gattung Mimela wurden im Gebiet des Dalat-Plateaus in Südvietnam gefunden. Zehn von ihnen werden als neu für die Wissenschaft beschrieben. Die Mehrzahl der Arten scheint endemisch zu sein und hat Verwandte in der Sino-Himalaya-Region.

\section{Introduction}

Mimela Kirby, 1825 is a species-rich Anomaline genus containing about 200 species distributed mostly in the Oriental and East Palaearctic regions, with rather few species also in the West Palaearctic and tropical Africa. The species of Mimela from Vietnam were reviewed by PAUlian (1959) who recognized 22 species mostly from the northern part of the country. A single new species was added subsequently (NGUYEN and WADA, 2006). There is no recent revision, thus, the current knowledge on the diversity of Vietnamese Mimela is fairly incomplete. A considerable number of Mimela species has been described from the adjacent parts of China and Indochina in the past 50 years (SABATINELLI, 1994; LiN, 1966, 1990,
1993), of which several have been recorded from Vietnam too. However, a lot of undescribed species, especially from the poorly explored central and southern parts of the country, can be expected.

The current paper is dedicated to a review of Mimela from Dalat (= Langbian) Mountains, one of the least explored mountainous chains in the southernmost part of central Vietnam (approximately $11-13^{\circ} \mathrm{N}, 107-109^{\circ} \mathrm{E}$ ). Together with the adjoining Daclac Mountains, it forms an isolated mountain area separated from the southernmost part of Truong Son (= Annam) Mountain Chain (Kontum Plateau) by low altitudes. The highest elevation is Mt. Yang Sin (2423 m asl), three other peaks (Hon Giao, 
Lang Bian or Nui Ba, and Bi Doup) are above $2000 \mathrm{~m}$ asl, most part of the plateau is around $1500 \mathrm{~m}$ asl. The recent collecting trips reveal a highly diverse and mostly endemic Anomaline fauna in this area (i.e., ZorN, 2011; Prokofiev, 2012a, 2012b, 2013a, 2013b, 2013c, 2015a, 2015b), however, the genus Mimela was not treated in the previous papers. Herein we recognize 12 species from this area, of which ten species are described as new to science.

\section{Methods and material}

All measurements of entire specimen are based on combined length of head, pronotum and elytra, measured individually. Characters and specimens were examined using a dissecting stereo microscope and fiber optic illumination. Habitus images were modified with stacking and graphics software (CombineZP, Adobe Photoshop CS3).

Label data are cited in exactly the same way as they were originally given on the labels. Separate labels are separated by 'l'. Type specimens of the species described in this paper bear the following labels: "Holo-/Paratypus Mimela [species epithet] sp. nov. det. Prokofiev et Zorn [year]".

The following acronyms are used for the names of the institutions and private collections where the specimens used in this study are deposited:

CAP Collection Artem Prokofiev; will be housed in the Zoological Museum, Moscow State University, Moscow, Russia

CCZ Collection Carsten Zorn, Gnoien, Germany

MNHN Muséum national d'Histoire naturelle, Paris, France

MZUF Università di Firenze, Museo Zoologico "La Specola", Italy

CPP Collection Petr Pacholátko, Brno, Czech Republic

UMO University Museum Oxford, Great Britain

CVM Collection Vladislav Malý, Prague, Czech Republic

ZMB Museum für Naturkunde der Humboldt-Universität, Berlin, Germany

\section{Mimela amphichroma spec. nov.}

(Figs 1, 2, 15-17)

Holotype: $0^{\star}$ "VIETNAM, Lam Dong prov., Lac Duon distr., Bi Doup - Nui Ba Natl. Park, Hon Giao Pass, $12^{\circ} 10 ' 58^{\prime \prime} \mathrm{N}$, $108^{\circ} 42^{\prime} 50^{\prime \prime} \mathrm{E}$, alt. $1625 \mathrm{~m}$, at light, 23-24.4.2012, A.M. Prokofiev leg. | [holotype label]" (CAP).

Paratypes: $7 \sigma^{\prime}, 8$ ㅇ "VIETNAM, Lam Dong prov., Lac Duon distr., Bi Doup - Nui Ba Natl. Park, alt. 1500$1625 \mathrm{~m}$, at light, 5.2009, A.M. Prokofiev leg. | [paratype label]" (CAP). 32 o , 33 우, [same data as above but 4.2010] | [paratype label]" (CAP). $250^{\star}, 16$ [ [same data as above but 4-5.2012] | [paratype label] (CAP).
Description (holotype): Length $14.0 \mathrm{~mm}$, greatest width $8.0 \mathrm{~mm}$. Deep-green above, reddish-testaceous below; clypeus, anterior part of frons, antennae, and side margins of pronotum yellow to testaceous; elytra and pygidium with yellowish tint; tarsi darker than the other parts of legs; protibial teeth margined with black; pilosity pale. Clypeus almost rectangular, with anterior angles broadly rounded, anterior margin straight, weakly raised. Frontoclypeal suture distinct. Clypeus finely transversely rugose, more coarsely in the middle. Frons coarsely, rugosely punctate in the anteriormost part, punctures becoming well but somewhat unevenly spaced posteriad, less dense in outer thirds than along mid-line. Pronotum twice broader than long, sides almost parallel in basal half, distinctly convergent in anterior half; anterior angles produced, sharp; posterior angles weakly obtuse, shortly rounded. Anterior margin of pronotum with marginal line, weakly bisinuate; posterior margin of pronotum strongly convex in the middle third, indistinctly concave in outer thirds, marginal line interrupted before scutellum. Pronotum rather coarsely but very unevenly punctured, punctures being much denser and more coarse in the middle third of each half of pronotum, becoming finer and sparser toward the sides and middle of disc; there are only few very fine punctures in the area before the scutellum. Midline of pronotum with short distinctly impressed groove; there is a distinct oblique impression before the posterior angles. Scutellum finely and unevenly punctured. Posterior margin of scutellum ogival. Surface of head, pronotum and scutellum with very fine microsculpture which is less developed on elytra. Elytra deeply and slightly unevenly punctured, punctures simple, well-spaced; punctate rows of elytra obvious, with a single row of punctures close to the suture and three double rows on disc of each elytron. Sides of elytra with marginal line, except the apical quarter, epipleura with a row of distant short setae, the latter longer and more numerous under humeral umbo. Pygidium convex, coarsely and unevenly punctured (punctures becoming denser at sides), glabrous except for moderately long and sparse setae along outer margin.

Prosternal process well-developed, plough-shaped, bluntly pointed anteriorly. Mesometasternal process very short, bluntly pointed. Sides of sterna coarsely, rugosely punctate and setose, with rather long but not dense adpressed hairs; disc of metasternum glabrous, impressed. Sides of abdominal sternites finely but irregularly rugosely punctate, punctures becoming very fine and sparse toward middle; glabrous, except for a transverse row of short distant setae in the middle of each sternite, and for the last visible sternite, which possesses short distant setae along posterior border.

Protibia bidentate, teeth closely spaced, inner spur attached just behind the level of apex of basal tooth. Last joint of fore tarsi moderately thickened, toothed at midlength of its ventral margin. Inner fore claw broadened, strongly excavated at base of its ventral margin, with lobes slightly divergent, lower lobe twice broader than upper at base. Outer claw of middle tarsi cleft. 
Aedeagus: Figs 15-17.

Female: Antennal club shorter. Pygidium less convex, setae along outer margin slightly more numerous. Teeth of protibia blunter, apical tooth longer and broader. Inner spur attached well behind basal tooth of protibia. Last joint of fore tarsi somewhat broadened distally, only slightly indented near middle of its margin; inner claw narrow, with lower lobe only 1.5 times broader than the upper one at base. Vaginal palpi triangular, densely setose.

Variations (both sexes): Length 13.5-15.0 (usually about $14.0) \mathrm{mm}$, greatest width $7.0-8.5 \mathrm{~mm}$. Density of punctation of dorsal surface (especially on head) is variable, surface of most closely punctured parts of pronotum in many cases wrinkled between punctures, especially in the females. Length of pronotum is somewhat variable.

Two color morphs exist. The green form varies from deepgreen to greenish-yellow from above, in extreme cases (most pale variants) the head is completely yellowishtestaceous with greenish tint on vertex, pronotum with a pair of deep-green spots on disc; pygidium green with outer margin yellowish. The violet form is coffee-red to violet brown from above, with pronotum and pygidium usually (sometimes also disc of elytra) darker; pronotum with or without yellowish side margins, in some cases pygidium also with yellowish outer border. The underside is usually darker than in the green form. Live beetles have a pronounced violet tint disappearing in dry specimens. In both forms the tarsi can have the same color as the other parts of legs or can be darker. No transitional forms between both color forms were observed yet, but structurally and in genitalia shape they are identical.

Differential diagnosis: Mimela amphichroma is very similar to M. plicatulla LIN, 1990 so far known from Yunnan, but the apices of the parameres are much more strongly curved in M. amphichroma (compare fig. 14 in LIN (1990) and figs 61-63). A violet color form is unknown in M. plicatulla.

It is similar also to Mimela abdominalis OHAUs, 1902, but differs from the latter species in the irregular (vs. regular) punctation of the head, in the much more pronounced medial sulcus and impressions at the hind angles of pronotum, in the very uneven punctation of pronotum (vs. pronotum rather regularly, coarsely and densely punctured, punctures becoming smaller and somewhat sparser toward the anterior and side margins of pronotum in M. abdominalis) and in the fine (vs. coarse) punctation of the scutellum.

Distribution: So far known only from the Dalat Plateau, South Vietnam.

Etymology: The species name is derived from the Greek prefix " $\alpha \mu \varphi$ " (double) and the noun " $\chi \rho \omega \mu \alpha$ " (color), alluding to the existence of two color morphs in this species, to be used as noun in apposition.
Mimela campyloclados spec. nov.

(Figs 3, 18-22)

Holotype: क“ "VIETNAM, Binh Thuan prov., $45 \mathrm{~km} \mathrm{SW}$ Phan Thiet, My Thanh vill., $10^{\circ} 05.530^{\prime} \mathrm{N}, 107^{\circ} 54.450^{\prime} \mathrm{E}$, alt. $180 \mathrm{~m}$, monsoon forest, at light, 13-16.5.2012, A.M. Prokofiev leg. | [holotype label]" (CAP).

Paratypes: $10^{\star}, 2$ \% [same label as for holotype] | [paratype label] (CAP).

Description (holotype): Length $15 \mathrm{~mm}$, greatest width $8.5 \mathrm{~mm}$. Reddish-testaceous with strong opalescent metallic-green, partly cupreous luster above, on pygidium and legs, at certain light traces of rosy lights in apical third of elytra inward from apical protuberances; tarsi darker than other parts of legs; pilosity pale.

Clypeus subrectangular, with sides very indistinctly convergent anteriad, anterior angles broadly rounded, not distinct; anterior margin straight, weakly raised. Fronto-clypeal suture distinct. Clypeus coarsely, rugosely punctate; anteriormost part of frons rugosely punctate, punctures becoming separated posteriad, fine and sparse on vertex. Pronotum 2.2 times broader than long, sides almost parallel in basal half, distinctly convergent and weakly convex in anterior half; anterior angles produced, sharp; posterior angles weakly obtuse, shortly rounded. Anterior margin of pronotum with marginal line which is disappearing in the middle, concave and almost straight medially; posterior margin of pronotum strongly convex in middle third, indistinctly concave in outer thirds; basal border interrupted before scutellum. Sides of pronotum with few distant long erect hairs. Pronotum, scutellum and elytra very finely and scantily punctured; punctate rows of elytra hardly traceable. Posterior margin of scutellum broadly rounded. Sides of elytra with marginal line, with elytral epipleura thickened, bearing a row of short and sparse setae, becoming very distant behind humeral umbo. Pygidium strongly convex, finely transversely rugose at base, finely punctured in other parts, with sparse erect moderately long hairs at outer edge.

Prosternal process well-developed, plough-shaped, pointed anteriorly, with sharp posterior ventral corner. Mesometasternal process absent. Sides of sterna finely, rugosely punctate and setose, with short, not dense adpressed hairs; disc of metasternum glabrous, weakly impressed. Abdominal sternites with a transverse row of sparse rather short adpressed hairs along midline of sternite; last visible sternite glabrous with a row of very short setae along distal border.

Protibia bidentate, teeth closely spaced, inner spur attached just behind the level of apex of basal tooth. Last joint of fore tarsi thickened, strongly toothed at middle of its concave margin. Inner fore claw broadened, its ventral margin excavated at base, with lobes almost parallel, lower lobe about three times broader than upper at base. Outer claw of middle tarsi cleft.

Aedeagus: Figs 18-22. 
Female: Antennal club shorter. Pygidium less convex. Hairs on pygidium and abdominal sternites somewhat longer than in the males. Apical tooth of protibia much longer, broader, finger-like. Inner spur attached well behind basal tooth of protibia. Last joint of fore tarsi somewhat broadened distally, only slightly indented at middle of its concave margin; inner claw narrow, with lower lobe only 1.5 times broader than the upper one at base. Vaginal palpi triangular, densely setose.

Variations (both sexes): Length $15.0-17.0 \mathrm{~mm}$, greatest width $8.5-9.5 \mathrm{~mm}$. Frons sometimes more coarsely, rugosely punctate in most of its surface; in such cases punctures on vertex also better developed and more numerous. Sides of pronotum sometimes more distinctly rounded, weakly convergent toward the posterior angles. Anterior margin of pronotum sometimes very weakly convex in the middle.

Differential diagnosis: Mimela campyloclados is extremely similar to M. ignistriata LIN, 1990 known from Yunnan and northern Thailand, but differs in not having fiery red to purple oblique stripes on elytra. Moreover, the left paramere of the aedeagus is less strongly bent compared to $M$. ignistriata (Figs 23-25) and continuously attenuate instead of subapically thickened. SABATINELLI (1994) already noticed the difference of the aedeagus between M. ignistriata specimens from northern Thailand and one specimen from Annam, but refrained from description. Mimela langbianica and M. ngoclinhensis NGUyen \& WADA, 2006 also show the same type of asymmetric aedeagus, but can easily be differentiated by their leaf-green (M. langbianica) and metallic green (M. ngoclinhensis) dorsal color.

Distribution: So far known only from the Dalat Plateau, South Vietnam.

Etymology: The species epithet is Latinized from

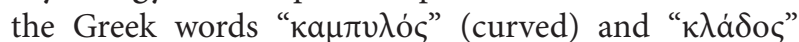
(branch), alluding to the curved left paramere of the aedeagus.

\section{Mimela dalatocoerulea spec. nov.}

(Figs 4, 26-28)

Holotype: ${ }^{*}$ "S VIETNAM, 30 km NW Dalat Long Lanh v. $1400 \mathrm{~m}, 12.04 .07$, P. Udovichenko leg. [holotype label]" (CCZ).

Paratypes: 2 ๙ , 3 + "VIETNAM, 30 km NW Dalat Long Lanh v. 1400 m, 12.04.07, P. Udovichenko leg. I paratype label" (CAP, CCZ).

Description (holotype): Length $14.6 \mathrm{~mm}$; greatest width $8.8 \mathrm{~mm}$. Entirely dark blue; legs, especially tibiae with metallic green luster depending on incident angle of light; pilosity pale.
Clypeus trapezoidal with the anterior angles rounded; anterior margin nearly straight, moderately raised. Frontoclypeal suture distinct; with few erect setae along inner margin of eye; clypeus densely rugosely punctate; frons densely punctate; punctures becoming gradually finer and scarcer toward vertex which is almost smooth at base; pronotum ca. 1.72 times broader than long; sides parallel in the posterior $2 / 3$; strongly convergent toward the acute and produced anterior angles; lateral area distinctly bulging; posterior angles obtuse but well-marked; anterior margin nearly straight in the middle, marginal line entire, only somewhat indistinct in the very middle; posterior margin very weakly bisinuate, produced in the middle, with strong marginal line which is interrupted before the scutellum; scutellum broadly ogival; punctation of pronotum and scutellum extremely fine, moderately dense; elytra with larger, but shallow punctures arranged in double rows (primary costae) and irregularly in the 4 inner interstices plus a very minute and scarce intermixed irregular punctation; three inner rows distinctly sulcate at apex; humeral umbo and apical protuberance very prominent; sides of elytra strongly bulging between anterior third and apical protuberance; lateral margin not visible from above in this area; pygidium strongly convex, bulging, with somewhat indistinct transverse punctures in the basal third, otherwise almost smooth with scarce microscopic punctures; with few scarce, rather short setae at apex and anterolateral angles.

Prosternal process well developed, plough-shaped, pointed anteriorly, with a sharp posterior ventral corner, forming a little dent; mesometasternal process absent. Sides of sterna finely, rugosely punctate and setose; with rather short, semi-erect, moderately dense hairs; disc smooth, glabrous, with impressed middle line. Abdominal sternites with somewhat denser punctation laterally, otherwise almost glabrous with very faint, scarce punctures; each sternite with an indistinct transverse row of distant semi-erect hairs; distal margin of last visible sternite sinuate, with a row of dense hairs.

Protibia bidentate, teeth closely spaced; inner spur attached at level of apex of basal tooth; last joint of fore tarsi thickened, weekly toothed in the middle of its concave margin; inner fore claw broadened, its ventral margin excavated at base and with an obtuse dent in the middle, with lobes almost parallel; outer claw of middle tarsi cleft, lower lobe 3-4 times broader than the upper at base. Aedeagus: Figs 26-28.

Female: Antennal club shorter. Lateral portion of pronotum distinctly bulged. Apical tooth of protibia much longer and spatulate. Inner spur attached well behind basal tooth of protibia. Last joint of fore tarsi only slightly indented at middle of its concave margin; inner claw narrow, with lower lobe only 1.5 times broader than the upper one at base.

Variation (both sexes): Length $14.0-15.8 \mathrm{~mm}$, width 8.9-9.4 mm. 
Differential diagnosis: Mimela dalatocoerulea spec. nov. is a sibling species of M. linpingi SabatinelLI, 1994 described from northern Thailand but also occurring in Yunnan and Laos. It is externally different from the latter by the longitudinal bulge at the sides of elytra which is hiding the lateral margin in dorsal view. The parameres of $M$. dalatocoerulea are distinctly longer with a subapical dent at the upper inner margin. The dagger-shaped apical process of the ventral plate is longer (compare figs 9-10 in SABATINelli (1994) and figs 64-66.

Etymology: The species epithet is a combination of Dalat (the region of origin) and the Latin adjective "coeruleus, $-a,-u m$ ", meaning "blue from Dalat".

\section{Mimela dehaani (HoPE, 1839)}

(Figs 5, 29-31)

Material: 5 `, 4 ㅇ "VIETNAM, Lam Dong prov., Lac Duong distr., Bi Doup - Nui Ba Natl. Park, alt. 1500-1625 m, at light, 4.2010, 4-5.2012, A.M. Prokofiev leg." (CAP).

Type material: Euchlora dehaani Hope: Syntype: $10^{\star}$ “TYPE HOPE Proc. Zool. Soc. 2. 1839. P. 71 Coll. Hope Oxon. Euchlora DeHaani Hope [Hope's handwritten label] | DeHaani Hope [Hope's handwritten label] | Mimela dehaani, Hope. teste,c 1910. G.J. Arrow. in Brit. Mus. | TYPE COL: 565 Euchlora dehaani Hope HOPE DEPT.OXFORD" (UMO).

Mimela decipiens Hope: Syntypes: $10^{\star}$ "TYPE HOPE Trans. Ent. Soc. 3. 1841 P. 66 Coll. Hope Oxon. | Mimela decipiens Hope [Hope's handwritten label] | Mimela dehaani, Hope. teste,c 1910. G.J. Arrow. in Brit. Mus. | TYPE COL: 566 1/1 Mimela decipiens Hope HOPE DEPT.OXFORD” (UMO). 1 i “Decipiens [Hope's handwritten label] | TYPE HOPE Trans. Ent. Soc. 3. 1841 P. 66 Coll. Hope Oxon. | Mimela dehaani, Hope. teste,c 1910. G.J. Arrow. in Brit. Mus. | TYPE COL: 566 2/2 Mimela decipiens Hope HOPE DEPT.OXFORD” (UMO).

Mimela dulcissima Bates: Syntype: 1 o $^{*}$ "SzeChuen China | Mimela dulcissima Bates | Ex-Musaeo H.W.BATES 1892 | SYNTYPE Mimela dulcissima Bates, 1891 det. Zorn, $2002 "(\mathrm{MNHN})$.

Remarks: Our specimens from Dalat Plateau do not differ from the type specimens of Euchlora dehaani Hope, 1839, Mimela decipiens Hope, 1841 and M. dulcissima BATES, 1891 (UMO, MNHN, examined) from Himalaya and Southwestern China, of which the conspecificity was proved earlier (ZoRN, 2005).

\section{Mimela galbinata spec. nov.}

(Figs 6, 32-35)

Holotype: o" "VIETNAM, Lam Dong prov., Lac Duong distr., Bi Doup - Nui Ba Natl. Park, betw. Hon Giao \&
Giang Ly, DT 723, 33 km E Dasar, 70 km W K. Vinh, $12^{\circ} 10.94^{\prime} \mathrm{N}, 108^{\circ} 41.47^{\prime} \mathrm{E}$, alt. $1500 \mathrm{~m}$, at light, 30-31.5. 2012, A.M. Prokofiev leg. | [holotype label]" (CAP).

Paratypes: 10 "S VIETNAM, 28.-30.4.1994 $12 \mathrm{~km} \mathrm{~N}$ of Dalat-LangBian P. Pacholátko \& L. Dembický leg. | AV 58 | Coll. P. Pacholátko Invt.No. | [paratype label]" (CPP). 1 ơ "S VIETNAM, 28.-30.4.1994 12 km N of Dalat-LangBian P. Pacholátko \& L. Dembický leg. | AV 58 | [paratype label]" (CPP). 7 o , 1 우 “S VIETNAM,12.03N 108.27E 12 km N ofDalat - Lang Bian 1580-1750 m, 17-21-iv.1995 Pacholátko \& Dembický leg. | Coll. P. Pacholátko Invt.No. | [paratype label]" (CCZ, CPP). 20 o , 13 ㅇ "VIETNAM, Lam Dong prov., Lac Duong distr., Bi Doup - Nui Ba Natl. Park, alt. 1400-1700 m, at light, 5.2009, A.M. Prokofiev leg. | [paratype label]" (CAP). 40 o , 26 ㅇ, [same data as above but 4.2010] | [paratype label]" (CAP). 35 o , 38 ㅇ, [same data as above but 4-5.2012] | [paratype label]" (CAP). $10^{*}$ "Lam Dong Prov., Lac Duong Dist. Bidoup Nuiba Natl Park, surr. Giang Ly Ranger Station (1420$1460 \mathrm{~m}$ a.s.l.) 16-21.VI.2015 at light | legit L. Bartolozzi, G. Chelazzi, S. Bambi, F. Fabiano, E. Orbach, V. Sbordoni (n. Magazzino 3023) | [paratype label]" (MZUF). 2 o $^{*}$ "C VIETNAM: Kon Tum Province, ca. $30 \mathrm{~km}$ from

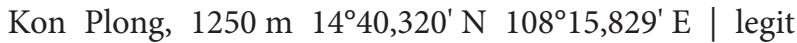
L. Bartolozzi, S. Bambi, A. Bandinelli, V. Sbordoni (Mag. 3078) | [paratype label]" (CCZ, MZUF).

Description (holotype): Length $13.5 \mathrm{~mm}$, greatest width $6.8 \mathrm{~mm}$. Greenish-testaceous, shining from above, head and pronotum darker; reddish-testaceous below; legs reddish-brown, tarsi darker, teeth of protibia infuscated; antennae reddish-testaceous, club darker; pilosity pale.

Clypeus trapezoidal, with sides convergent anteriad, anterior angles broadly rounded, not distinct; anterior margin straight, clearly raised. Fronto-clypeal suture conspicuous, forming a short branch (less conspicuous) to inner-anterior border of eye, which completely separating the canthus ocularis. Clypeus and anterior part of frons coarsely and rugosely punctate, punctures becoming smaller and much sparser toward the vertex. Pronotum 1.9 times broader than long, sides almost parallel in basal half, distinctly convergent and slightly concave in anterior half; anterior angles produced, sharp; posterior angles straight, well-marked. Anterior margin weakly bisinuate, with marginal line in lateral thirds; posterior margin of pronotum slightly bisinuate, with middle part (before scutellum) much more convex, straightened; posterior border of pronotum weak and interrupted far before scutellum. Sides of pronotum with few long erect distant hairs. Pronotum moderately densely, rather finely punctured, punctures becoming smaller toward the sides. Scutellum sparsely, finely and rather unevenly punctured, distal margin ogival. Elytra finely but densely punctured; punctures in interspaces slightly irregular; punctate rows hardly discernible. Sides of elytra with marginal line, with elytral epipleura thickened below humeral umbo, along all length bearing 


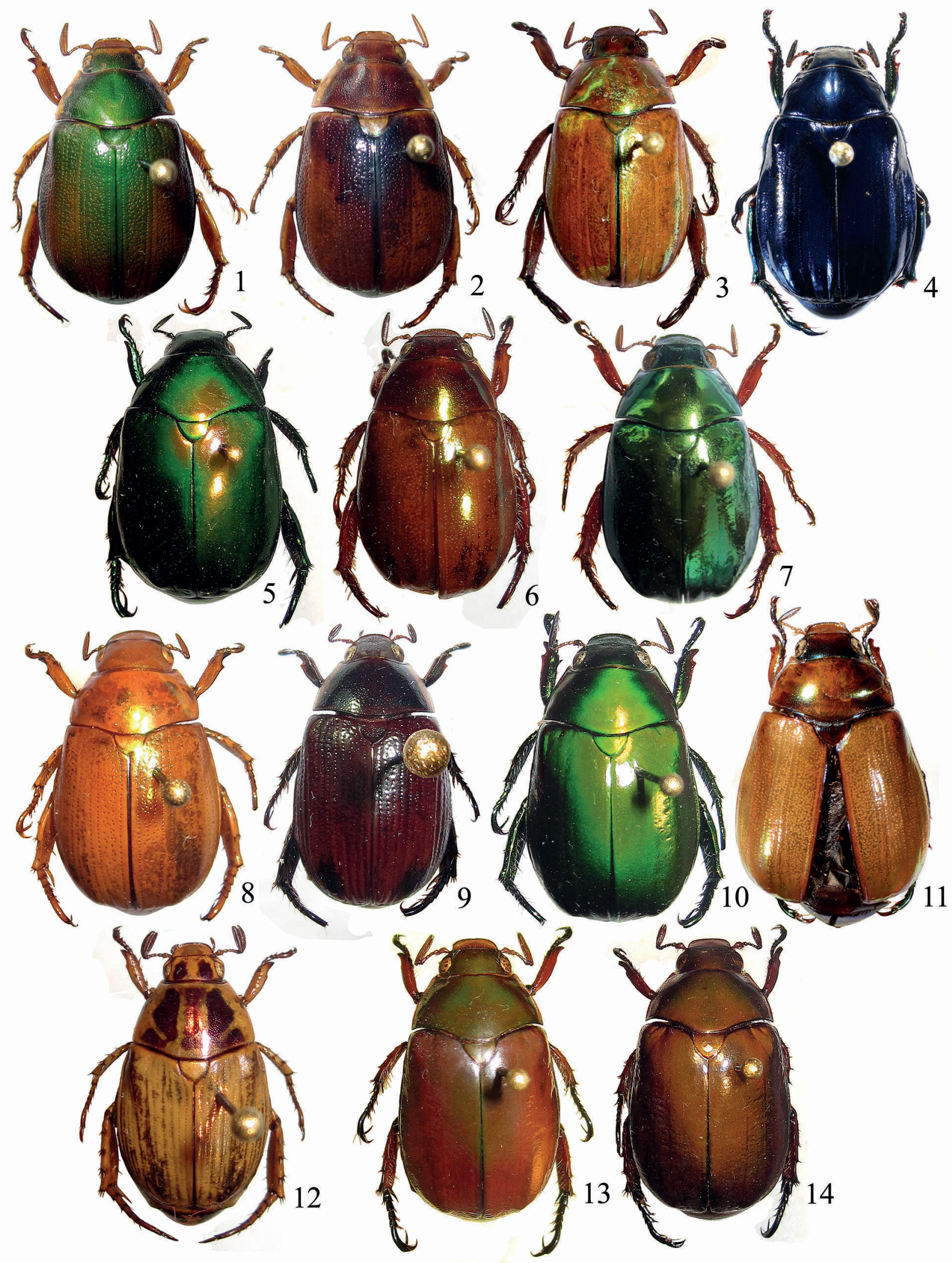

Figs 1-14: Mimela spp. - 1, 2 M. amphichroma spec. nov. (1 green form, holotype; 2 violet form, paratype, male). 3 M. campyloclados spec. nov., holotype. $4 \mathrm{M}$. dalatocoerulea spec. nov., holotype. $5 \mathrm{M}$. dehaani, male, Vietnam: Lamdong prov. 6 M. galbinata spec. nov., holotype. 7 M. germana spec. nov., holotype. 8 M. indosinica spec. nov., holotype. 9 M. krasava spec. nov., holotype. 10 M. langbianica spec. nov., holotype. $11 \mathrm{M}$. pacholatkoi spec. nov., holotype. $12 \mathrm{M}$. signaticollis, male, Vietnam: Nha Trang. 13, 14 M. vietnamensis spec. nov. (13. male, holotype. 14. female, paratype). 
rather dense and long setae. Pygidium not very convex, finely and sparsely punctured, with long erect hairs at apex only.

Prosternal process well-developed, plough-shaped, bluntly pointed anteriorly. Mesometasternal process very short, truncate. Sides of sterna coarsely, rugosely punctate and setose, with rather long but not dense adpressed hairs; disc of metasternum bare, glabrous, weakly impressed. Abdominal sternites with several transverse rows of rather long but sparse semi-erect hairs, which are much longer in middle third of penultimate visible sternite; last visible sternite bearing a transverse row of rather short hairs along midline and much longer hairs along distal border.

Protibia bidentate, teeth closely spaces, inner spur attached at level of basal tooth. Last joint of fore tarsi thickened, indented at mid-length of its concave margin, with a short protrusion on each side at anteroventral corner. Inner fore claw broadened, slightly toothed at basal third, with lobes almost parallel, lower lobe twice broader than upper at base. Outer claw of middle tarsi cleft.

Aedeagus: Figs 32-35.

Female: Length $14.0 \mathrm{~mm}$, greatest width $8.5 \mathrm{~mm}$. Antennal club shorter. Side margin of elytra distinctly callose just behind middle. Apical tooth of protibia much longer and broader. Inner spur attached well behind basal tooth of protibia. Last joint of fore tarsi less broadened distally, indented at midlength of its concave margin; inner claw narrow, with lower lobe only 1.5 times broader than the upper one at base. Vaginal palpi of irregular shape, with double incised inner margin, apically setose.

Variations: Length $12.0-14.0 \mathrm{~mm}$, greatest width $6.3-7.3 \mathrm{~mm}$ (males), $13.0-15.0 \mathrm{~mm}$ (few larger than $14 \mathrm{~mm}$ ), greatest width 7.0-8.5 mm (females). Greenish luster on dorsal surface variable. In extreme cases head and pronotum greenish-brown, elytra yellowish to reddish testaceous with slight greenish luster. Clypeus and frontoclypeal suture sometimes margined by blackish-green. Pronotum 1.9-2.0 times broader than long, anterior border sometimes very indistinctly bisinuate, sides in anterior half sometimes almost straight, in posterior half sometimes slightly convergent toward base; posterior angles straight to weakly obtuse. Punctation of scutellum sometimes quite regular. Punctation of pygidium slightly varies in size and density of punctures.

Differential diagnosis: Mimela galbinata is a close relative of M. epipleurica OHAUs, 1930, a species described from a (single?) female from Lao Cai, Vietnam. The true identity of M. epipleurica is still a little uncertain because no males from the type locality have ever been found. The application of the name M. epipleurica to a species occurring in Yunnan by LIN (1990) has yet to be confirmed even if this species appears to be externally identical to the syntype, and such distribution pattern would be very plausible. Mimela galbinata from Dalat is different from M. epipleurica in the following characters: color more testaceous dorsally (dark metallic green in M. epipleurica), yellowish coloration of the lateral margin of pronotum broader, sutural costa less raised in the posterior two thirds of elytra, body shape somewhat rounder and shorter, the epipleural lateral bulge of females less developed. Males of M. epipleurica have a more flattened protibia than those of $M$. galbinata. The aedeagus is very different from M. epipleurica sensu LIN, 1990 (figs 67-69) with the parameres more asymmetric and distinctly shorter. The right paramere is much more strongly bent downward.

Distribution: So far known only from the Dalat Plateau, South Vietnam.

Etymology: The species epithet is formed by the Latin adjective "galbinatus, - $a$, -um", meaning "dressing yellow-green".

Mimela germana spec. nov.

(Figs 7, 36-38)

Holotype: $0^{\star}$ "VIETNAM, Lam Dong prov., Lac Duong distr., Bi Doup - Nui Ba Natl. Park, Hon Giao Pass, $12^{\circ} 10^{\prime} 58^{\prime \prime} \mathrm{N}, 108^{\circ} 42^{\prime} 50^{\prime \prime} \mathrm{E}$, alt. $1625 \mathrm{~m}$, at light, 18-19.4.2010, A.M. Prokofiev leg. | [holotype label]" (CAP).

Paratypes: 1 우 [same label as for holotype] | [paratype label]" (CAP). 2 “ "VIETNAM, Lam Dong prov., Lac Duong distr., Bi Doup - Nui Ba Natl. Park, $5 \mathrm{~km} \mathrm{E}$ Dinh K’No, $12^{\circ} 08^{\prime} 25^{\prime \prime} \mathrm{N}, 108^{\circ} 23^{\prime} 24^{\prime \prime}$ E, alt. 1510-1520 m, at light, 19-21.4.2010, A.M. Prokofiev leg. | [paratype label]" (CAP). 1 \% , 4 \% "VIETNAM, Lam Dong prov., Lac Duong distr., Bi Doup - Nui Ba Natl. Park, betw. Hon Giao \& Giang Ly, DT 723, $33 \mathrm{~km}$ E Dasar, $70 \mathrm{~km} \mathrm{~W}$ K. Vinh, $12^{\circ} 10.94^{\prime} \mathrm{N}, 108^{\circ} 41.47^{\prime} \mathrm{E}$, alt. $1500 \mathrm{~m}$, at light, 30-31.5.2012, A.M. Prokofiev leg. | [paratype label]" (CAP).

Description (holotype): Length $14.0 \mathrm{~mm}$, greatest width $8.5 \mathrm{~mm}$. Deep metallic-green above, dark reddish-brown below; legs dark reddish-brown, with tarsi more infuscated; antennae reddish-testaceous; pilosity pale.

Clypeus almost rectangular, with anterior angles broadly rounded; anterior margin straight, clearly raised. Frontoclypeal suture distinct. Clypeus coarsely, rugosely punctate; anterior part of frons less rugosely punctate, punctures becoming much sparser toward the vertex, with minute not dense punctures between them. Rather long sparse hairs along inner margin of eye. Pronotum 2.5 times broader than long, sides almost parallel in basal half, distinctly convergent in anterior half; anterior angles produced, sharp; posterior angles straight, shortly rounded. Anterior margin weakly bisinuate, with marginal line in lateral thirds; posterior margin of prono- 
tum considerably convex at middle part, straightened laterally; posterior margin of pronotum with narrow marginal line in lateral thirds. No traces of medial pronotal sulcus. Sides of pronotum with few long erect distant hairs. Pronotum finely and sparsely punctured, with minute sparse punctures between punctures, discernible under high magnification. Scutellum similarly but somewhat more finely and much more unevenly punctured, distal margin ogival. Elytra distinctly convex, sides somewhat broadened posteriad. Elytra finely and moderately densely punctured, with minute punctures between the larger ones; punctate rows hardly discernible. Sides of elytra with marginal line, with elytral epipleura thickened and bearing a row of short and sparse setae. Pygidium moderately convex, finely and very unevenly punctured, with punctures becoming much denser toward the laterobasal angles but very sparse and uneven on disc; minute punctures between the larger ones hardly discernible; pygidium glabrous except for a row of long erect hairs along apical border.

Prosternal process well-developed, plough-shaped, pointed anteriorly. Mesometasternal process very short and bulging. Sides of sterna rugosely punctate and setose, with rather long but not dense adpressed hairs; disc of metasternum glabrous, impressed. Abdominal sternites with a transverse row of rather long but sparse adpressed setae along mid-length; last visible sternite with a transverse row of much longer semi-erect hairs along distal border, the latter somewhat thickened.

Protibia bidentate, teeth widely spaced, basal tooth small; inner spur attached slightly behind the level of basal tooth; fore tarsi attached at level of mid-length of space between protibial teeth. Last joint of fore tarsi thickened, strongly toothed just behind mid-length of its concave margin. Inner fore claw broadened, with lobes slightly divergent, lower lobe about 3 times broader than upper at base. Outer claw of middle tarsi cleft.

Aedeagus: Figs 36-38.

Female: Length $17.5 \mathrm{~mm}$, greatest width $8.5 \mathrm{~mm}$. Antennal club shorter. Body somewhat more elongated than in male. Side margin of elytra the same as in the male, not callose. Apical tooth of protibia much longer and broader. Inner spur attached well behind basal tooth of protibia, longer than in male. Fore tarsi attached at level of basal tooth. Last joint of fore tarsi weakly thickened, indented just behind mid-length of its concave margin; inner claw narrower, with lower lobe about 2 times broader than the upper one at base. Vaginal palpi oblong and rather narrow, rounded at tip, setose.

Variations: Length $13.5-15.0 \mathrm{~mm}$, greatest width $7.5-8.5 \mathrm{~mm}$ (males), $16.0-17.0 \mathrm{~mm}$ and $8.0-8.5 \mathrm{~mm}$ (females). Pronotum 2.0-2.5 times broader than long. Expression of punctate rows of elytra slightly varies from specimen to specimen. In worn specimens dorsal punctation seems to be finer and intermixed minute punctures may be hardly visible.
Differential diagnosis: This species is a very close relative of M. rectangular Lin, 1990 (figs 39, 40) known from North Vietnam, northern Thailand, Laos and Yunnan. It differs from $M$. rectangular as follows: sculpture of frons and clypeus less rugose; the pronotum finely and scantily punctured (vs. coarsely and densely punctured) always lacking middle sulcus; sides of pronotum not margined by yellow; clypeus always entirely green (at least apical half of clypeus is yellow in $M$. rectangular); parameres longer and narrower, with their ventral margin not thickened; basal plate with slightly shorter and broader recurved tip.

Distribution: So far known only from the Dalat Plateau, southern Vietnam.

Etymology: The species epithet is formed by the Latin adjective "germanus, - $a$, -um", meaning "brotherly", in allusion to the close relations to $M$. rectangular.

\section{Mimela indosinica spec. nov.}

(Figs 8, 41-43)

Holotype: $0^{*}$ "VIETNAM, Binh Thuan prov., $45 \mathrm{~km} \mathrm{SW}$ Phan Thiet, My Thanh vill., $10^{\circ} 05.530^{\prime} \mathrm{N}, 107^{\circ} 54.450^{\prime} \mathrm{E}$, alt. $180 \mathrm{~m}$, monsoon forest, at light, 13-16.5.2012, A.M. Prokofiev leg. | [holotype label]" (CAP).

Paratypes: $1 \sigma^{x}, 1$ i [same label as for holotype] | [paratype label]” (CAP). 10 o", 12 \% “THAI 21.-26.v.1993 NAMUANG Pacholatko \& Dembicky leg. | [paratype label]” (CCZ, CPP). 2 đ`, 4 ㅇ “THAI 20.v.1993 NAKHON THAI Pacholatko \& Dembicky leg. | [paratype label]” (CCZ, CPP). 1 o "S VIETNAM, 1.-15.5.1994 Nam Cat Tien Nat. park P. Pacholátk \& L. Dembický leg. | [paratype label]" (CPP). 1 o $^{*}$ "Thailand Exp. 30.3.-2.5.86 Koll. Lehmann | [paratype label]" (CCZ). $10^{*}$ "LAOS centr. 27.iv.-1.v.1997 $70 \mathrm{~km}$ NE Vientiane, BAN PHABAT env. $150 \mathrm{~m} \mathrm{~N} 18^{\circ} 16.1 \mathrm{E} 103^{\circ} 10.9$, M. Strba \& Hergovits leg. | [paratype label]" (CCZ). $10^{*}$ "LAOS, Bolikhamxai pr. $18^{\circ} 10^{\prime} \mathrm{N} 103^{\circ} 11^{\prime} \mathrm{E}, 70 \mathrm{~km}$ NEE Vientiane 27.-30.iv. 1997, 150 m, Vit Kubán leg. | [paratype label]" (CPP). $10^{*}$ "LAOS centr., Bolikhamsai prov. BAN NAPE Laew Nua Pass, 18.4.-1.5.1988, alt. $600 \pm 100 \mathrm{~m}, \mathrm{~N} 18^{\circ} 22.3$ E $105^{\circ} 09.1$ (GPS), M. Strba \& R. Hergovits) | coll Vladislv Malý Česka Rep. Praha | [paratype label]” (CVM).

Description (holotype): Length $13.0 \mathrm{~mm}$, greatest width $7.0 \mathrm{~mm}$. Testaceous, with strong metallic-green luster above, on pygidium and legs; abdomen much darker, reddish-brown; pilosity pale.

Clypeus subrectangular, with sides indistinctly convergent anteriad, anterior angles rounded; anterior margin straight, raised, tall in frontal view. Fronto-clypeal suture distinct. Clypeus finely, rugosely punctate, frons and vertex finely punctate, punctures becoming smaller and sparser toward the vertex. Pronotum 2.14 times broader than long, sides almost parallel in basal half, distinctly convergent in anterior half; anterior angles sharp; posterior angles weakly 
obtuse, shortly rounded. Anterior margin concave, almost straight in middle, with complete marginal line; posterior margin of pronotum convex, much more protruding in middle third, with marginal line in its outer thirds only. Pronotum and scutellum very finely and minutely punctured; outer margin of scutellum ogival. Punctures of elytra slightly more coarse and distinct, punctures simple, somewhat irregular in the subsutural, 2nd and 3rd interstice, but primary punctate rows regular and distinct. Sides of elytra with marginal line, with elytral epipleura thickened, glabrous. Pygidium strongly convex, finely and scantily punctured, with sparse but quite long erect hairs at apex and on most bulging portion.

Prosternal process well-developed, plough-shaped, pointed anteriorly (with tip slightly inclined downward), its posterior ventral angle very weakly produced backward; sides with fine vertical rugosities. Mesometasternal process indistinct. Sides of sterna coarsely, rugosely punctate, with punctures ocellate, setigerous, with rather sparse adpressed hairs moderate in length; disc of metasternum glabrous, weakly impressed, with few sparse setae laterally. Abdominal sternites with a transverse row of distant moderately short setae just behind mid-line; last visible sternite with similar but somewhat denser setae along distal border.

Protibia bidentate, teeth closely spaced, inner spur attached at level of basal tooth. Last joint of fore tarsi thickened, indented at mid-length of its concave margin. Inner fore claw broadened, with lobes almost parallel, lower lobe twice broader than upper at base. Outer claw of middle tarsi cleft.

Aedeagus: Figs 41-43.

Female: Length $13.5 \mathrm{~mm}$, greatest width $7.5 \mathrm{~mm}$. Antennal club shorter. Pygidium less convex. Protibia with blunter teeth, apical tooth much longer, broader, finger-like. Inner spur attached well behind basal tooth of protibia. Last joint of fore tarsi much less broadened distally but similarly indented on curved margin; inner claw narrower, with lower lobe only 1.5 times broader than the upper one at base. Vaginal palpi triangular, setose.

Variations: Length $12.5-16.0 \mathrm{~mm}$, greatest width $7.8-9.1 \mathrm{~mm}$.

Differential diagnosis: Mimela indosinica is very similar to M. laotina OHAUs, 1930, but is different in the following characters: body shape slightly more ovoid and stouter, elytra distally more enlarged in M. laotina, punctures of elytra rather small and weekly impressed in $M$. indosinica (vs. elytral punctures large and deeply impressed with convex primary striae in M. laotina), elytra with the same color and strong shine like pronotum (less shining and slightly lighter than pronotum in M. laotina), hind tibia more strongly fusiform in $M$. indosinica. The aedeagus of M. indosinica is quite different with much more pointed and elongate parameres which have an subapical inner tooth. The ventral plate is apically not extended like in M. laotina (figs 70-72).
Distribution: South Vietnam: Dalat plateau, Laos: Bolikhamxai prov., Thailand: Phitsanulok prov.

Etymology: The species epithet is formed by the Latin adjective "indosinicus, $-a$, - um", referring to the Indochinese distribution of this species.

\section{Mimela krasava spec. nov.}

(Figs 9, 44-46)

Holotype: $0^{*}$ "VIETNAM, Khanh Hoa prov., Khanh Vinh distr., $72 \mathrm{~km}$ E Dalat, $12^{\circ} 14^{\prime} 08^{\prime \prime} \mathrm{N}, 108^{\circ} 46^{\prime} 14^{\prime \prime} \mathrm{E}$, alt. 750-800 m, at light, 5.6.2012, A.M. Prokofiev leg. | [holotype label]" (CAP).

Paratype: $0^{*}$ "VIETNAM, Khanh Hoa prov., Khanh Vinh distr., $\sim 3 \mathrm{~km}$ above felling, $12^{\circ} 13.422^{\prime} \mathrm{N}, 108^{\circ} 45.535^{\prime} \mathrm{E}$, alt. $916 \mathrm{~m}$, at light, 4.6.2012, A.M. Prokofiev leg. | [paratype label]" (CAP).

Description (holotype): Length $8.5 \mathrm{~mm}$, greatest width $4.5 \mathrm{~mm}$. Reddish-brown above, pronotum with strong dark-green tint and broad yellowish side margins; apical protuberances of elytra with oblong blackish marks descending toward side border; sterna and pygidium testaceous, abdomen much darker, reddish-brown; legs testaceous, except most parts of protibia and upper and inner parts of meso- and metatibia, which are metallic green-brown, tarsi reddish-brown to blackish, hind tarsi darker; antennae reddish-brown, club darker; pilosity pale.

Clypeus nearly trapezoidal, with sides convergent anteriad, anterior angles broadly rounded, not distinct; anterior margin straight, weakly raised, narrow in frontal view. Outer part along outer margin distinctly impressed, finely punctured, convex central and basal parts of clypeus coarsely, rugosely punctate. Fronto-clypeal suture distinct. Inner margin of eye with fine marginal line, with a single erect seta inserted before its mid-length on each side (perhaps other setae worn off). Eyes somewhat bulging. Anterior half of frons rugosely punctate, slightly impressed at center, punctures becoming smaller and much sparser toward vertex. Pronotum 1.9 times broader than long, sides almost parallel in basal half, distinctly convergent in anterior half; anterior angles acute; posterior angles obtuse, rounded. Anterior margin of pronotum with complete marginal line, concave; posterior margin of pronotum strongly convex in middle third, straightened in outer thirds, basis with complete marginal line. Sides of pronotum with few long erect distant hairs. Pronotum regularly and distinctly, moderately dense punctured, spaces between punctures on disc more or less equal with their diameter, punctures becoming smaller toward the margins. Scutellum subtriangular with apex bluntly pointed, irregularly punctured; punctures similar to those on the disc of pronotum. Elytra with distinct punctate rows having deep simple punctures and slightly convex interspaces; second interspace with irregular punctation narrowed into a single row in posteri- 
ormost quarter, $4^{\text {th }}, 6^{\text {th }}$ and $8^{\text {th }}$ interspaces with a single row of punctures; punctures in even interspaces the same as in punctate rows; odd interspaces with minute somewhat irregular punctures. Sides of elytra with marginal line, with elytral epipleura thickened under humeral umbo, bearing short distant setae, longer and more closely spaced under humeral umbo. Pygidium weakly convex, rugosely punctate, with a double row of rather long erect hairs at apex.

Prosternal process well-developed, plough-shaped, bluntly pointed anteriorly, its ventral margin conspicuously sloping anteriad, posterior ventral angle with small but distinct anteriorly recurved tooth. Mesometasternal process indistinct. Sides of sterna somewhat rugosely punctate, with short and rather sparse adpressed hairs; disc of metasternum glabrous, impressed. Abdominal sternites coarsely punctured, punctures smaller and denser at upper sides, each sternite with a transverse row of well spaced rather long semierect setae, which are conspicuously longer on penultimate sternite; last visible sternite with similar setae along distal border.

Protibia bidentate, apical tooth long, basal tooth welldeveloped, inner spur attached at level of basal tooth. Last joint of fore tarsi thickened apically, indented at mid-length of its concave margin. Inner fore claw broadened, with lobes slightly divergent, lower lobe 2.5 times broader than upper at base, its ventral margin distinctly convex. Outer claw of middle tarsi cleft. Metatarsal joints distinctly thicker than pro- and mesotarsal joints. Hind tibiae fusiform. Long spur of hind tibiae evenly doublecurved, narrow but blunt at apex.

Aedeagus: Figs 44-46.

Variation: Punctation of pronotum somewhat coarser and punctation of scutellum denser and more regular in the second male; black apical marks on elytra indistinct and not covering apical protuberances in the paratype.

Female: unknown.

Differential diagnosis: Small size, color and punctation pattern of elytra make this new species look extremely similar to Anomala felicia Arrow, 1910 from Borneo, however, the well developed prosternal process places this species in the genus Mimela. The closest relatives appear to be the small Sundanian species M. discoidea Burmeister, 1844, M. vethi Ohaus, 1913 and Mimela nana LANSBERge, 1879. The aedeagus of Mimela krasava is very different from those species in having apically somewhat raised and pointed parameres. Moreover, all known similar Mimela species from Malaysia, Sumatra and Java are more or less testaceous.

Distribution: So far known only from the Dalat Plateau, South Vietnam.

Etymology: The species epithet is derived from a Russian word meaning "beautiful", to be used as noun in apposition.

\section{Mimela langbianica spec. nov.}

(Figs 10, 47-50)

Holotype: ‘ "VIETNAM, Lam Dong prov., Lac Duong distr., Bi Doup - Nui Ba Natl. Park, betw. Hon Giao \& Giang Ly, DT 723, 33 km E Dasar, $70 \mathrm{~km} \mathrm{~W} \mathrm{K.} \mathrm{Vinh,}$ $12^{\circ} 10.94^{\prime} \mathrm{N}, 108^{\circ} 41.47^{\prime} \mathrm{E}$, alt. $1500 \mathrm{~m}$, at light, 30-31.5.2012, A.M. Prokofiev leg. | [holotype label]” (CAP).

Paratypes: 12 ๙, 7 \& "VIETNAM, Lam Dong prov., Lac Duong distr., Bi Doup - Nui Ba Natl. Park, alt. 1400$1700 \mathrm{~m}$, at light, 5.2009, A.M. Prokofiev leg. | [paratype label]" (CAP). $12 \sigma^{\star}, 7$ ㅇ, [same data as above but 4.2010] | [paratype label]" (CAP). $37 \sigma^{\star}, 19$ 우 [same data as above but 4-5.2012] | [paratype label]" (CAP). 4 o , 2 우 "S VIETNAM, 28.-30.4.1994 $12 \mathrm{~km}$ N of Dalat-LangBian P. Pacholátko \& L. Dembický leg. | Coll. P. Pacholátko Inv. No. | [paratype label]" (CCZ, CPP). 2 o "S VIETNAM, 28.-30.4.1994 $12 \mathrm{~km} \mathrm{~N}$ of Dalat-LangBian P. Pacholátko \& L. Dembický leg. | AV66 | Coll. P. Pacholátko Inv.No. | [paratype label]" (CPP). 43 o , 17 \& "S VIETNAM, 28.-30.4.1994 $12 \mathrm{~km} \mathrm{~N}$ of Dalat-LangBian P. Pacholátko \& L. Dembický leg. | [paratype label]" (CCZ, CPP). $20^{\star}$ "S Vietnam, $12.03 \mathrm{~N}$ 108.27E, $12 \mathrm{~km} \mathrm{~N}$ of Dalat Lang Bian, 1580-1750 m, 17.-21.IV.1995, Pacholátko \& Dembický leg. | [paratype label]” (CPP). 37 o , 16 ㅇ "S Vietnam, 12.03N 108.27E, $12 \mathrm{~km} \mathrm{~N}$ of Dalat - Lang Bian, 1580-1750 m, 17.-21.IV.1995, Pacholátko \& Dembický leg. [paratype label]” (CCZ, CPP).

Description (holotype): Length $15.0 \mathrm{~mm}$, greatest width $9.5 \mathrm{~mm}$. Leaf-green, darker below, shining; pro-, mesoand metafemora with weak orange-brown tint; antennae reddish-brown, club much darker; pilosity pale.

Clypeus trapezoidal, with sides convergent anteriad, anterior angles broadly rounded, not distinct; anterior margin straight, weakly raised. Fronto-clypeal suture distinct. Inner margin of eye with indistinct marginal line, with a few erect setae. Clypeus coarsely, rugosely punctate, punctures similarly rugose and only slightly less dense in anteriormost part of frons, becoming sparser and finer posteriad; surface of frons and vertex with fine shagreenlike microsculpture. Pronotum twice broader than long, sides almost parallel in basal half, distinctly convergent in anterior half; anterior angles produced, sharp; posterior angles weakly obtuse, shortly rounded. Anterior margin of pronotum with marginal line in outer quarters, weakly bisinuate; posterior margin of pronotum convex, especially in the middle third, with indistinct traces of border in its outer thirds. Sides of pronotum with few long erect distant hairs. Pronotum, scutellum and elytra very finely and sparsely punctured, surface with fine shagreen-like microsculpture; punctate rows of elytra very weakly discernible. Posterior margin of scutellum ogival. Sides of elytra with marginal line, with elytral epipleura thickened, bearing rather long sparse setae. Pygidium strongly convex, sparsely but coarsely punctured (punctures being 
much denser but smaller along its base), punctures setigerous, with long erect hairs.

Prosternal process well-developed, plough-shaped, bluntly pointed anteriorly. Mesometasternal process very short, truncate. Sides of sterna coarsely, rugosely punctate and setose, with rather long but not dense adpressed hairs; disc of metasternum bare, glabrous, impressed. Sides of abdominal sternites with several rows of moderately long semi-erect hairs extending into a single transverse row along each sternite; last visible sternite glabrous with sparse hairs along distal border.

Protibia bidentate, teeth closely spaces, inner spur attached at level of basal tooth. Last joint of fore tarsi thickened, toothed just behind mid-length of its concave margin. Inner fore claw broadened, somewhat curved, with lobes slightly divergent, lower lobe about three times broader than upper at base. Outer claw of middle tarsi simple.

Aedeagus: Figs 47-50.

Female: Antennal club shorter. Pygidium less convex. Apical tooth of protibia much longer, broader, finger-like. Inner spur attached well behind basal tooth of protibia. Last joint of fore tarsi somewhat broadened distally, only slightly indented just behind middle of its concave margin; inner claw narrow, with lower lobe only 1.5 times broader than the upper one at base. Vaginal palpi triangular, densely setose.

Variations (both sexes): Length 14.0-17.7 mm, greatest width $8.5-11.0 \mathrm{~mm}$. Pro-, meso- and metafemora vary from green with slight orange-brown tint to completely orange-brown; sides of abdominal sternites sometimes with cupreous luster; apical margin of pygidium sometimes changes to orange-brown; $1^{\text {st }}$ joint of antennae (scapus) sometimes partially green. Density of punctation of frons and vertex highly variable, in extreme cases the anteriormost part of frons being rather sparsely though coarsely punctured and vertex being similarly punctured as pronotum. Pronotum 2.0-2.1 times as broad as long. Pygidium in some specimens more densely and coarsely punctured than in the others.

Differential diagnosis: Although resembling other leafgreen Mimela species like M. dehaani, M. glabra Hope, 1841 etc. at first sight, the peculiar asymmetric aedeagus indicates a very close relationship to $M$. ignistriata, M. ngoclinhensis and M. campyloclados spec. nov. with very different coloration (metallic green or brownish with more or less present fiery red longitudinal stripes).

Distribution: So far known only from the Dalat Plateau, South Vietnam.

Etymology: The species epithet is referring to the type locality, Langbian (= Dalat) Plateau.

\section{Mimela pacholatkoi spec. nov.}

(Figs 11, 51-53)

Holotype: “o "S VIETNAM,12.03N 108.27E $12 \mathrm{~km} \mathrm{~N}$ of Dalat - Lang Bian 1580-1750 m, 17-21-iv.1995 Pacholátko \& Dembický leg. | AV 56 | [holotype label]" (CPP). Paratypes: 3 ㅇ «S VIETNAM,12.03N 108.27E $12 \mathrm{~km} \mathrm{~N}$ of Dalat - Lang Bian 1580-1750 m, 17-21-iv.1995 Pacholátko \& Dembický leg. | [paratype label]" (CCZ, CPP). 1 ㅇ «S VIETNAM,12.03N 108.27E $12 \mathrm{~km} \mathrm{~N}$ of Dalat Lang Bian 1580-1750 m, 17-21-iv.1995 Pacholátko \& Dembický leg. | AV 56 | [paratype label]" (CPP).

Description (holotype): Length $15.2 \mathrm{~mm}$, greatest width $9.5 \mathrm{~mm}$. Dorsally orange-brown (elytra slightly lighter) with vivid metallic iridescent reflections; elytra with fiery red discoidal and lateral longitudinal stripes alternating with green-blue stripes stretching along suture and from humeral umbo to apical protuberance, expression of stripes very much depending on perspective and incidence angle of light; clypeus and forehead with fiery red to coppery shine, vertex and periocular area dark metallic green; pronotum with two vague green-blue patches near the hind angle; pygidium with fiery red to coppery disk, dark green along its margins; antenna orange brown with dark club; ventral face dark metallic green with fiery red to purple patches at sides of abdominal sternites; legs brown (femora slightly lighter) with metallic shine; apices of tibiae and tarsi very dark metallic green, almost black.

Clypeus trapezoidal, anterior angles broadly rounded, anterior margin slightly curved, weakly raised; frontoclypeal suture distinct, slightly sinuate; with scarce erect setae along inner margin of eye; clypeus rugosely punctate; frons very densely, partly confluently punctate, punctures rather fine; vertex with very fine, scarce punctation; pronotum ca. 1.9 times broader than long; sides subparallel in basal half, distinctly convergent in anterior half toward the acute and produced front angles; posterior angles obtuse, slightly rounded; anterior and posterior marginal beads broadly interrupted in the middle; posterior protruding in the middle third, nearly straight at the sides; sides with few distant hairs; disc with very fine, distant, shallow punctures; scutellum slightly transverse with very scarce and faint punctures; posterior margin ogival with rounded apex; elytra with moderately coarse and dense punctures, with regular double rows of punctures (primary costae) and irregularly punctate interstices; only the three inner rows sulcate at apex; sides of elytra with marginal line except the most apical section; epipleura with a row of distant short setae; pygidium convex, irregularly and somewhat transversely punctured, almost glabrous with scarce setae only at apex and baso-lateral angles.

Prosternal process well developed, plough-shaped. rather strongly pointed anteriorly; mesometasternal process not produced; sides of sterna coarsely, very densely and rugosely punctate, with long, semi-erect hairs; disc of metasternum glabrous, impressed; sides of abdominal 
sternites densely rugosely punctate, punctures becoming fine and scarce toward the middle; each sternite with a transverse row of hairs; which are scarce medially and dense at the sides.

Protibia bidentate, both teeth distinct and acute; inner spur attached distinctly behind the level of base of basal tooth; last joint of protarsus not thickened; inner fore claw broadened and strongly excavated at the base of its ventral margin; lower lobe three times broader than the upper at base; lower lobe distinctly pointing downward; outer claw of middle tarsi cleft.

Aedeagus: Figs 51-53.

Females: Pygidium more flat and transverse; antennal club slightly shorter; terminal tooth of protibia spatulate; inner protarsal claw slender, its lower branch only slightly broader than the upper.

Variations (females): length $14.8-15.7 \mathrm{~mm}$, greatest width $8.5-9.3 \mathrm{~mm}$. The extent of the blue-green markings on head and pronotum are variable, they are missing completely in one female.

Differential diagnosis: According to the very similar aedeagus the new species appears to be the closest known relative of M. ohausi ARrow, 1908, occurring in northern Thailand, Laos and Yunnan, but can be discriminated from the latter by being somewhat larger and usually by the orange-brown ground color with the described color pattern. However, there are also similar lighter color forms in the very variable $M$. ohausi. The extremely elongate aedeagus is quite similar to that of M. ohausi (fig. 54), but the apices of the parameres are less extended and rather straight (bent downward in M. ohausi).

Etymology: This species is dedicated to Petr Pacholátko, Brno, who generously provided the extensive Vietnamese Anomaline material of his collection to one of us (CZ).

\section{Mimela signaticollis OHAUS, 1902 (Figs 12, 55-57)}

Material: $3 o^{\star}, 5$ o "VIETNAM, Khanh Hoa prov., Nha Trang, 11.2010, 6.2012 and 4.2013, A.M. Prokofiev leg." (CAP). 4 + «VIETNAM, Khanh Hoa prov., Khanh Vinh distr. 70-72 km E Dalat, alt. 700-900 m, 4.2012, A.M. Prokofiev leg." (CAP). 1 i «VIETNAM, Binh Thuan prov., $\sim 30 \mathrm{~km}$ SW Phan Thiet, Ca Pet - Song Mong, $11^{\circ} 01.156^{\prime} \mathrm{N}, 107^{\circ} 52.218^{\prime} \mathrm{E}$, alt. $\sim 100 \mathrm{~m}$, at light, 11-12.5.2012, A.M. Prokofiev leg.» (CAP). $10^{x}, 1$ 우 "S Vietnam, 12.03N 108.27E, $12 \mathrm{~km} \mathrm{~N}$ of Dalat - Lang Bian, 1580-1750 m, 17.-21.IV.1995, Pacholátko \& Dembický leg." (CCZ). 1 q “Vietnam 07.09.2012, TF leg. Friedr. Schulz Madagui Provinz Lam Dong” (CCZ).
Type material: Syntypes: $1 \sigma^{\star}, 1+$ "Saigon Cochinchina | Mimela signaticollis Ohaus Type [Ohaus' handwritten label]" (ZMB).

Note: 5 i labelled “Tonkin Lao-kai | Mimela signaticollis Ohaus Cotype [Ohaus' handwritten label]" (ZMB) do not belong to the type series since OHAus (1902) based the description of this species on specimens from southern Vietnam (Saigon) and northern Vietnam (Phuc-Son) only. We were unable to locate the syntypes from PhucSon, which might be lost.

Remarks: Our specimens from Dalat Plateau and the adjoining coastal area around Nha Trang city are identical to the type specimens from Saigon. The clarification of the distribution range of $M$. signaticollis and the separation of this taxon from M. schulzei SABATINELLI, 1994 from Thailand as well as the question whether or not specimens from northern Vietnam (second type locality "Phuc-Son") are conspecific requires further study and possibly a lectotype designation.

\section{Mimela vietnamensis spec. nov (Figs 13, 14, 58-60)}

Holotype: ơ "VIETNAM, Lam Dong prov., Lac Duong distr., Bi Doup - Nui Ba Natl. Park, betw. Hon Giao \& Giang Ly, DT 723, $33 \mathrm{~km}$ E Dasar, $70 \mathrm{~km}$ W K. Vinh, $12^{\circ} 10.94^{\prime} \mathrm{N}, 108^{\circ} 41.47^{\prime} \mathrm{E}$, alt. $1500 \mathrm{~m}$, at light, 30-31.5.2012, A.M. Prokofiev leg. | [holotype label]" (CAP).

Paratypes: $10^{\star}, 1$ ㅇ "S VIETNAM, $30 \mathrm{~km}$ NW Dalat Long Lanh v., $1400 \mathrm{~m}, 12.04 .07$, P. Udovichenko leg. | [paratype label]" (CCZ). 3 \& «VIETNAM, Lam Dong prov., Lac Duong distr., Bi Doup - Nui Ba Natl. Park, Hon Giao Pass, $12^{\circ} 10^{\prime} 58^{\prime \prime} \mathrm{N}, 108^{\circ} 42^{\prime} 50^{\prime \prime} \mathrm{E}$, alt. $1625 \mathrm{~m}$, at light, 22-24.4.2010 and 23-24.4.2012, A.M. Prokofiev leg. | [paratype label]" (CAP). 2 + «VIETNAM, Lam Dong prov., Lac Duong distr., Bi Doup - Nui Ba Natl. Park, $12^{\circ} 06.215^{\prime} \mathrm{N}, 108^{\circ} 22.060^{\prime} \mathrm{E}$, alt. $1686 \mathrm{~m}$, at light, 27-29.5.2012, A.M. Prokofiev leg. | [paratype label]" (CAP).

Description (holotype): Length $15.5 \mathrm{~mm}$, greatest width $7.8 \mathrm{~mm}$. Clypeus and side margins of pronotum orangish, remaining part of head and pronotum, scutellum and anteriormost discal portion of elytra sericeous olive-green, other parts of elytra, abdomen (including pygidium) and tibiae reddish; basis of pronotum, outer margin of scutellum and all sides of elytra margined by black to blackish metallic green, distal tips of all tibiae and femora blackish, tarsi blackish; sterna, coxae and femora orange-testaceous; antennae orangish with surface of club joints with fine pale granulations; pilosity pale.

Clypeus rectangular with sides almost parallel, anterior angles rounded; anterior margin straight, weakly raised, tall in frontal view. Fronto-clypeal suture distinct. Inner 
margin of eye bearing few quite long erect setae. Clypeus coarsely punctured, punctures becoming indistinct toward the side and anterior margins, somewhat rugose in center; frons and vertex finely punctured, punctures becoming smaller and sparser posteriad. Pronotum about 2.2 times broader than long, sides evenly rounded, somewhat concave behind anterior angles; anterior angles produced, shortly rounded, almost straight; posterior angles weakly obtuse, shortly rounded. Anterior margin of pronotum without marginal line but with a transverse impression on each side at level of eye, concave, almost straight medially; posterior margin of pronotum strongly protruding before scutellum, weakly concave in outer thirds, without marginal line. Sides of pronotum with sparse long erect hairs. Pronotum very finely and rather sparsely punctured, punctures becoming distinctly larger and coarser at sides. Scutellum very finely and unevenly punctured, subtriangular with bluntly pointed apex. Elytra finely and regularly punctured; punctate rows of elytra indistinct. Sides of elytra with marginal line which disappears in the posteriormost quarter, elytral epipleura somewhat thickened below humeral umbo, bearing rather long sparse setae along all length which are somewhat denser under apical protuberance. Pygidium convex, impressed at side margins, coarsely but not very densely and somewhat irregularly punctured with transversely extended punctures, scantily setose with moderately long hairs.

Prosternal process well-developed, plough-shaped, bluntly pointed anteriorly, with broadly rounded posteroventral angle. Mesometasternal process moderately long, somewhat curved upward and pointed. Sides of sterna finely, somewhat rugosely punctured, setose, with rather long but not dense adpressed hairs; disc of metasternum glabrous, concave. Sides of abdominal sternites not very densely setose with short adpressed hairs continuing to a transverse row of moderately long, sparse hairs along mid-line of each sternite except the last visible one, which bears a row of hairs along its posterior margin.

Protibia almost unidentate, with only barely marked basal tooth, inner spur attached at level of a trace of basal tooth; apical tooth sharply acute. Last joint of fore tarsi moderately thickened, indented just behind mid-length of its concave margin. Inner fore claw broadened, excavated at base on its ventral margin, with lobes almost parallel, lower lobe twice broader than upper at base. Outer claw of middle tarsi shortly cleft.

Aedeagus: Figs 58-60.

Females: Length $16.0-18.0 \mathrm{~mm}$, greatest width $9.0-$ $10.4 \mathrm{~mm}$. Antennal club shorter. Clypeus punctate to rugosely punctate, density of punctures variable. Pygidium similar to that of males but somewhat more coarsely punctured. Upper sides of abdominal sternites with longer and denser pilosity than in the males. Protibia distinctly bidentate, with basal tooth weak but distinct, apical tooth of protibia much longer, broader, rounded at tip. Inner spur attached well behind basal tooth of protibia. Last joint of fore tarsi moderately thickened, indistinctly indented just behind middle of its concave margin; inner claw narrow, with lower lobe only 1.2 times broader than the upper one at base. Vaginal palpi triangular, setose.

Variations: Length (males) $15.5-17.2 \mathrm{~mm}$, greatest width $7.8-10.0 \mathrm{~mm}$. The elytra of the holotype are extensively suffused with reddish color whereas the paratypes are dorsally olive green, sometimes with orangish or reddish tint.

Differential diagnosis: Mimela vietnamensis is very closely related to Mimela passerinii Hope, 1842 of which several subspecies are present through the whole Himalaya, southern China, northern Indochina and Taiwan (some of which deserve rather species status in the opinion of the authors). Mimela passerinii diana LIN, 1993 from Yunnan, northern Thailand and northern Vietnam appears to be most similar to M. vietnamensis. However, none of the taxa subsumed under M. passerinii show such weakly and shallowly punctured and shining dorsal surface as $M$. vietnamensis. The pilosity in $M$. vietnamensis is generally less dense than in Mimela passerinii. An olive color form is also present in $M$. passerinii diana, but not in combination with the conspicuous metallic dark green margins of elytra. The mesosternal process is shorter compared to M. passerinii diana but not as short as in M. passerinii pomonae BATES, 1890. The parameres in M.vietnamensis are broader and shorter in lateral view compared to all M. passerinii subspecies, and the two apical extensions of the ventral plate are noticeably long and curved (compare fig. 10 in LIN (1993) and figs 73-75).

Etymology: The name of this species is derived from the country of its occurrence, Vietnam.

\section{Discussion}

The Dalat fauna of Mimela, as known at present, consists of 12 species. Eight of these species are only known from the Dalat Plateau and appear to be endemics according to the current knowledge. Two species have a rather wide distribution: M. dehaani (eastern Himalaya through northern and central Indochina to South-East China) and M. indosinica spec. nov. (southern Vietnam, Thailand and Laos). Mimela signaticollis is apparently more widespread in Thailand, Vietnam and Laos and found in altitudes lower than $1000 \mathrm{~m}$ and coastal zones, its exact distribution range, however, is yet unknown. The closest known relative is $M$. schulzei from northern Thailand and southern China, but the taxonomical separation of these two species as suggested by SABATINELLI (1994) appears to be somewhat problematic because of high variability in the aedeagus shape. Only one of the endemic species, M. krasava spec. nov., seem to have 
the closest relatives in Sundaland, all other species are closest related to species from northern Indochina, Himalaya and southern China.

In summary, the high degree of endemism of the Dalat fauna of Mimela is reflecting the biogeographical isolation of the Dalat Plateau, but several links to the adjacent Sino-Himalayan fauna are evident, either represented by close relatives of endemic species or the distribution range of more widespread species. Only one species from lower altitudes around $750-900 \mathrm{~m}$ is related to the Mimela fauna of Sundaland. Comparable biogeographical relations were also found in the butterfly fauna of Dalat (MONASTYrSKiI, 2010; MONASTYRSKiI and Holloway, 2013), however, Sundanian connections were more present in Rhopalocera. A half of 24 endemic Rhopaloceran species (50\%) of the Dalat plateau have Sundanian affinities (MonAstyrskiI, 2010: Table 3) instead of 1 of 8 endemic Mimela species (12.5\%). The amalgamation of Sino-Himalayan and Sundanian elements in the Dalat Plateau may be explained by the north-south route of mountains in Vietnam having allowed the former to migrate south in cooler climate

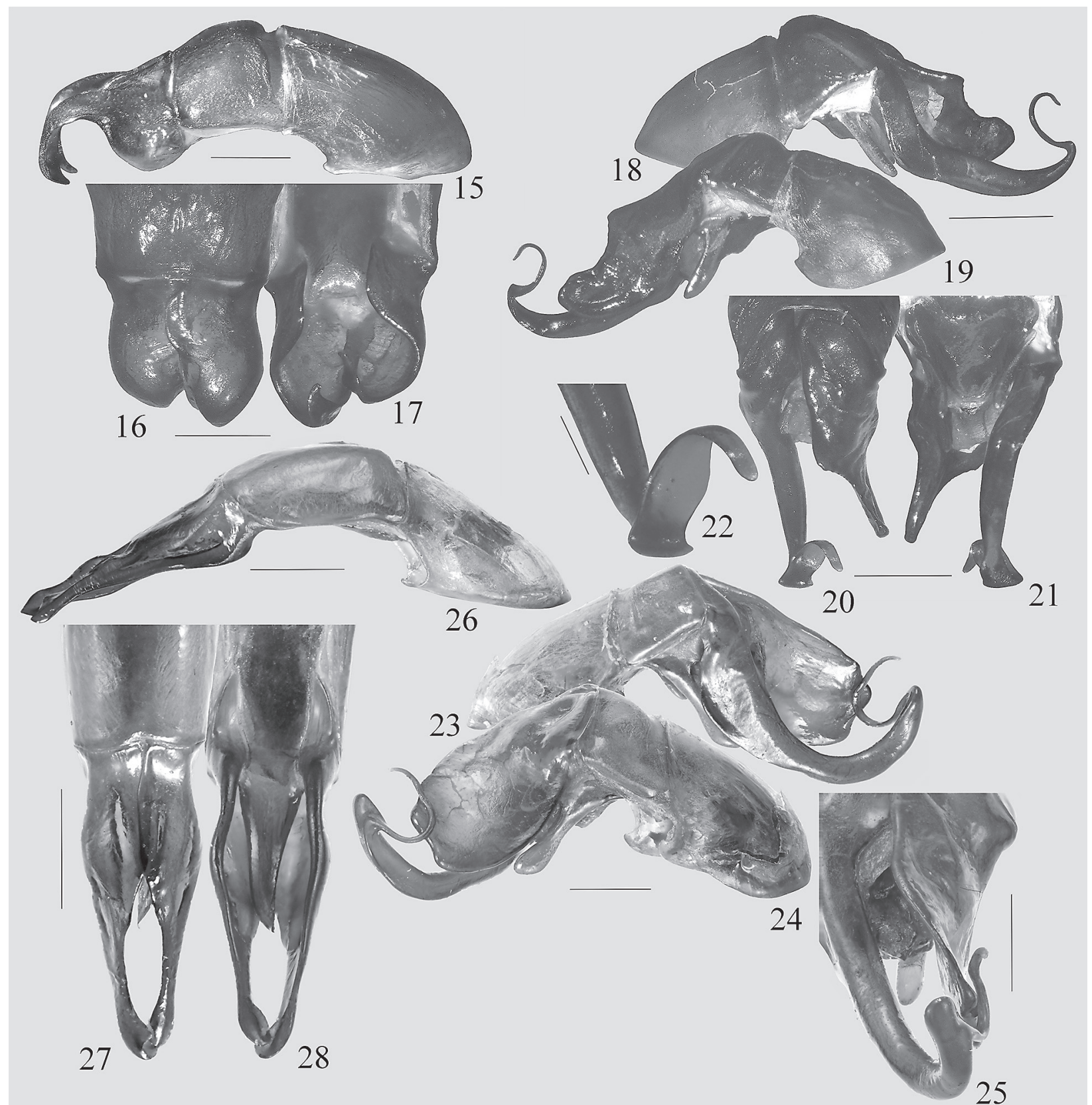

Figs 15-28: Mimela spp., aedeagi. - 15-17: M. amphichroma spec. nov., holotype (15 lateral view. 16 parameres, dorsal view. 17 parameres, ventral view). 18-22: M. campyloclados spec. nov., holotype (18 lateral view, right side. 19 lateral view, left side. 20 parameres, dorsal view. 21 parameres, ventral view. 22 distal tip of right paramere, dorsal view). 23-25: M. ignistriata, China: Yunnan prov., Ximeng. (23 lateral view, right side. 24 lateral view, left side. 25 dorsal view of parameres). 26-28: M. dalatocoerulea spec. nov., holotype (26 lateral view. 27 parameres, dorsal view. 28 parameres, ventral view). Scale bars: $18-21-2 \mathrm{~mm}, 22-0.5 \mathrm{~mm}$, others $-1 \mathrm{~mm}$. 
periods and the persistence of Sundanian humid forests in the maritime climate of the south of Vietnam during drier climate, providing a refuge for Sundanian elements (Monastyrskil and Holloway, 2013). However, according to our unpublished data Sundanian elements also of other genera aside from Mimela are underrepresented in the Dalat region even in lower altitudes (100-1000 m asl).

\section{Acknowledgements}

We wish to thank the collection managers and curators who made the material under their care available: Olivier Montreuil, Antoine Mantilleri, and Jean Menier (MNHN), Luca Bartolozzi (MZUF), Johannes Frisch, Berndt Jaeger, and Joachim Willers (ZMB), Darren J. Mann (UMO). We are greatly indepted to Petr Pacholátko (Brno) and Vladislav Malý (Prague) for providing specimens from their collections.

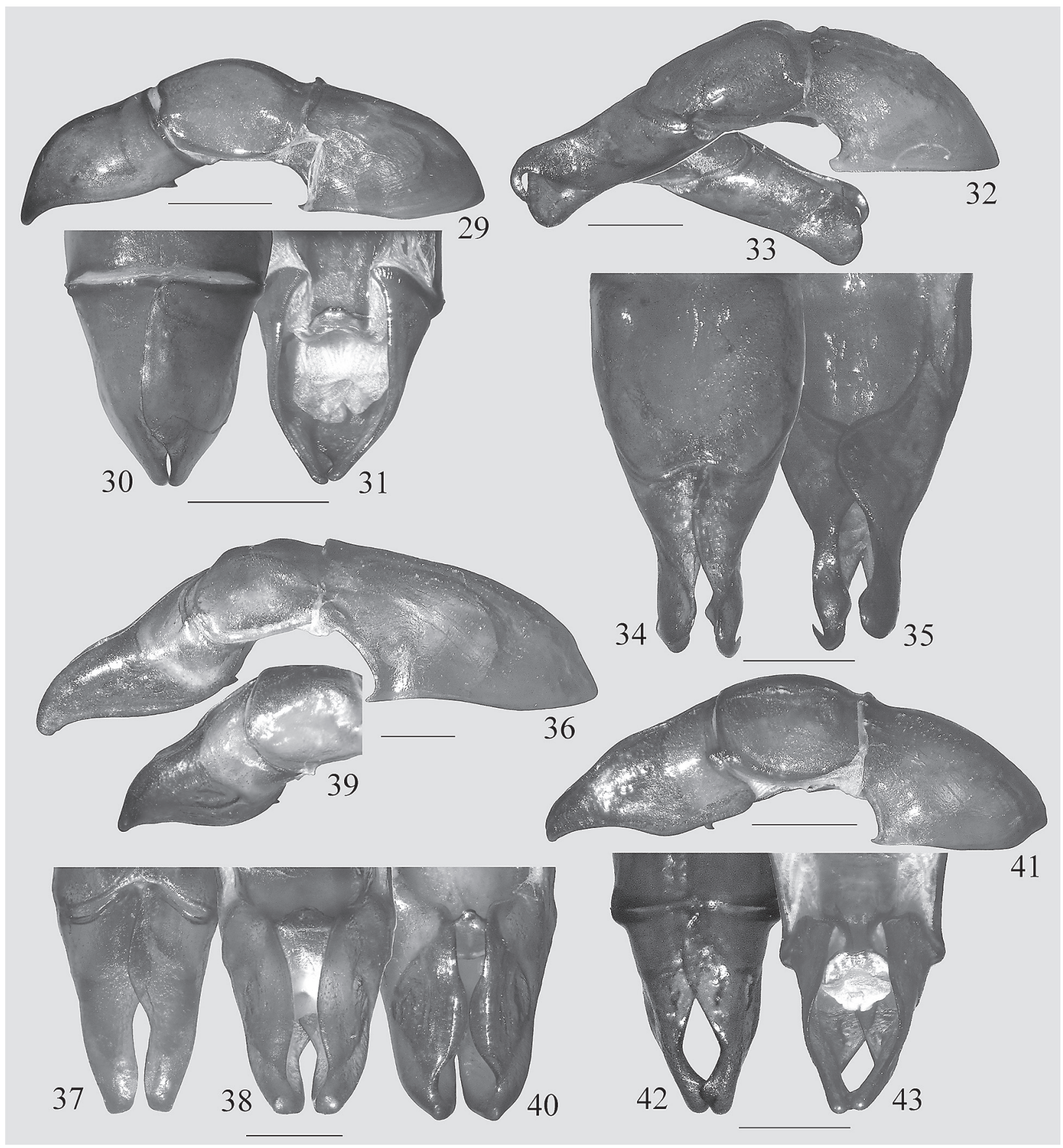

Figs 29-43: Mimela spp., aedeagi. - 29-31: M. dehaani, Vietnam: Lamdong prov. (29 lateral view. 30 parameres, dorsal view. 31 parameres, ventral view). 32-35: M. galbinata spec. nov. (32 lateral view, left side. 33 lateral view of parameres, right side. 34 parameres, dorsal view. 35 parameres, ventral view). 36-38: M. germana spec. nov. (36 lateral view. 37 parameres, dorsal view. 38 parameres, ventral view). 39, 40 M. rectangular, Laos: Khammouane prov. (39 lateral view of parameres. 40 ventral view of parameres). 41-43: M. indosinica spec. nov., holotype (41 lateral view. 42 parameres, dorsal view. 43 parameres, ventral view). Scale bars: $29-31-2 \mathrm{~mm}, 32-43-1 \mathrm{~mm}$. 


\section{Literature}

Arrow, G. J. 1908: On some new Species of the Coleopterous Genus Mimela. - The Annals and Magazin of Natural History including Zoology, Botany, and Geology (series 8) 1: 241-248.

Arrow, G. J. 1910: On a few new Bornean beetles of the Rutelid genera Mimela and Anomala. - The Annals and Magazine of natural History, including Zoology, Botany and Geology, London (series 8) 6: 64-72.

BAtes, H. W. 1890: Coleoptera collected by Mr. Pratt on the upper Yang-Tsze, and on the borders of Tibet. The Entomologist 23: 209-213, 244-247.

Burmeister, H. 1844: Handbuch der Entomologie. Vol. 4 (1), Coleoptera Lamellicornia Anthobia et Phyllophaga systellochela. Berlin: Enslin, ii + 587 pp.

Hope, F. W. 1839: A Monograph on Mr. William Sharp MacLeay's Coleopterous Genus Euchlora. - Proceedings of the Scientific Meetings of the Zoological Society of London 7: 65-75.

Hope F. W. 1841: Description of some new Lamellicorn Coleoptera from Northern India. - Transactions of the Entomological Society London 3[1841-1843]: 62-67.

Hope, F. W. 1842: On some rare and beautiful Insects from Silhet, chiefly in the collection of Frederic John Parry. - The Proceedings of the Linnean Society of London 1: 127-128.

Kirby, W. 1825: A Description of such Genera and Species of Insects, alluded to in the "Introduction to Entomology" of Messrs. Kirby and Spence, as appear not to have been before sufficiently noticed or described. - The Transactions of the Linnean Society of London 14: 563-572.

Lansberge, G. W. van 1879: Diagnoses de quelques espèces nouvelles de Buprestidae et de Scarabaéides de la Malaisie. - Annales de la Société entomologique de Belgique (Compte Rendus) 22: CXLVII-CLV.

Lin, P. 1966: New species of the genus Mimela Kirby (Coleoptera: Scarabaeidae). - Acta Zootaxonomica Sinica 3: 138-147.

LIN, P. 1990: New Species of the Genus Mimela (Coleoptera: Rutelidae) from South and Southwest China. - Entomotaxonomia 12: 19-26.

LIN, P. 1993: A systematic revision of the China Mimela: (Coleoptera: Rutelidae). - The Publishing Company of Zhong Shan University, 106 pp + xxii pl.

MonastyrskiI, A. L. 2010: On the origin of the recent fauna of butterflies (Lepidoptera, Rhopalocera) of Vietnam. - Entomology Review 90: 39-58.

MonastyrskiI, A. L. \& Holloway, J. D. 2013: The Biogeography of the Butterfly Fauna of Vietnam with a Focus on the Endemic Species (Lepidoptera): Pp. 95-123. - In: Silva-Opps, M. (ed.) Current Progress in Biological Research. Rijeka: Intech: 385 pp.

Nguyen, T. T. H. \& WAdA K. 2006: A new species of the genus Mimela (Coleoptera, Scarabaeidae, Rutelinae) from Vietnam. - Kogane 7: 61-64.
Ohaus, F. 1902: Neue Ruteliden. - Deutsche Entomologische Zeitschrift 1902: 49-58.

Ohaus, F. 1913: Neue Indomalayische Ruteliden. Tijdschrift voor Entomologie 56: 29-37.

Ohaus, F. 1930: XXVI. Beitrag zur Kenntnis der Rutelinen (Col. lamell.). - Deutsche Entomologische Zeitschrift 1930: $138-158$.

Ohaus, F. 1943: Revision der Gattung Mimela KIRBY (Col. Scarab. Rutelin.). - Deutsche Entomologische Zeitschrift 1943: 65-88.

Paulian, R. 1959: Coléoptères Scarabéides de L'Indochine (Rutélines et Cétonines) (Suite) - Annales de la Société entomologique de France 128: 1-102 (35-136).

Prokofiev, A. M. 2012a: Two new species of the genus Anomala Sam. from Central Vietnam (Coleoptera: Scarabaeidae). - Russian Entomological Journal 21: 385-393 [in Russian].

Prokofiev, A. M. 2012b: Adoretosoma atritarse dalatmontis subsp. nova (Coleoptera: Scarabaeidae: Rutelinae). - Amurian Zoological Journal 4: 336-339, pl. II [in Russian].

Prokofiev, A. M. 2013a: A new genus of Anomalini from Vietnam (Coleoptera: Scarabaeidae: Rutelinae. - Russian Entomological Journal 22: 5-7.

Prokofiev, A. M. 2013b: New Anomala species from Vietnam (Coleoptera: Scarabaeidae: Rutelinae). Russian Entomological Journal 22: 97-109.

Prokofiev, A. M. 2013c: Two new species of the Anomala aulax-group from Central Viet Nam (Coleoptera, Scarabaeidae, Rutelinae). - Euroasian Entomological Journal 12: 553-558.

Prokofiev, A. M. 2015a: New Anomala SAmouelle, 1819 from South-East Asia (Coleoptera: Scarabaeidae: Rutelinae). - Russian Entomological Journal 24: 37-59.

Prokofiev, A. M. 2015b: An unusual new species of the genus Anomala Samouelle, 1819 from Vietnam (Coleoptera: Scarabaeidae: Rutelinae). - Caucasian Entomological Bulletin 11: 25-27, pl. 4 [in Russian].

Sabatinelli, G. 1994: New Mimela species and Records from Thailand, Vietnam and Nepal (Coleoptera, Scarabaeoidea, Rutelidae). - Coleoptera, Schwanfelder Coleopterologische Mitteilungen 3: 57-71.

Zorn, C. 2005: Taxonomical acts in the Anomalini initiated during the preparation of the "Catalogue of Palaearctic Coleoptera”. Acta Societatis Zoologicae Bohemicae 68 [2004]: 310-328.

Zorn, C. 2011: New species of the genus Anomala Samouelle from mainland South East Asia and South China (Coleoptera: Scarabaeidae: Rutelinae). - Stuttgarter Beiträge zur Naturkunde A. Neue Serie 4: 297-312. 


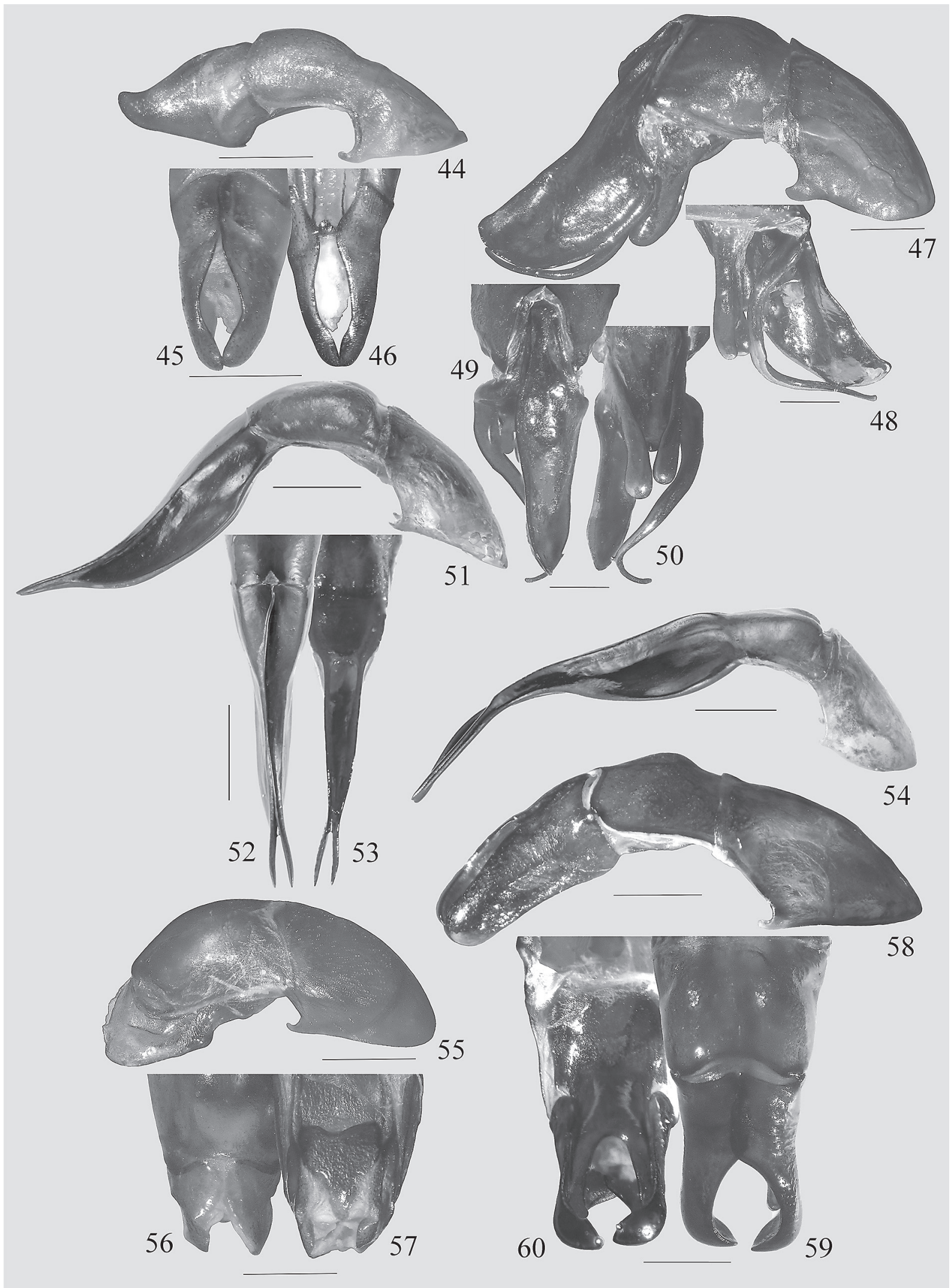

Figs 44-60: Mimela spp., aedeagi. - 44-46: M. krasava spec. nov., holotype (44 lateral view. 45 parameres, dorsal view. 46 parameres, ventral view). 47-50: M. langbianica spec. nov., holotype (47 lateral view, left side. 48 lateral view of parameres, right side. 49 dorsal view of parameres. 50 ventral view of parameres). 51-53: M. pacholatkoi spec. nov., holotype ( 51 lateral view. 52 parameres, dorsal view. 53 parameres, ventral view). 54 M. ohausi, Laos: Xieng Khouang prov., lateral view. 55-57: M. signaticollis, Vietnam: Nha Trang ( 55 lateral view. 56 parameres, dorsal view. 57 parameres, ventral view). 58-60: M. vietnamensis spec. nov., holotype (58 lateral view. 59 parameres, dorsal view. 60 parameres, ventral view). Scale bars: $1 \mathrm{~mm}$. 


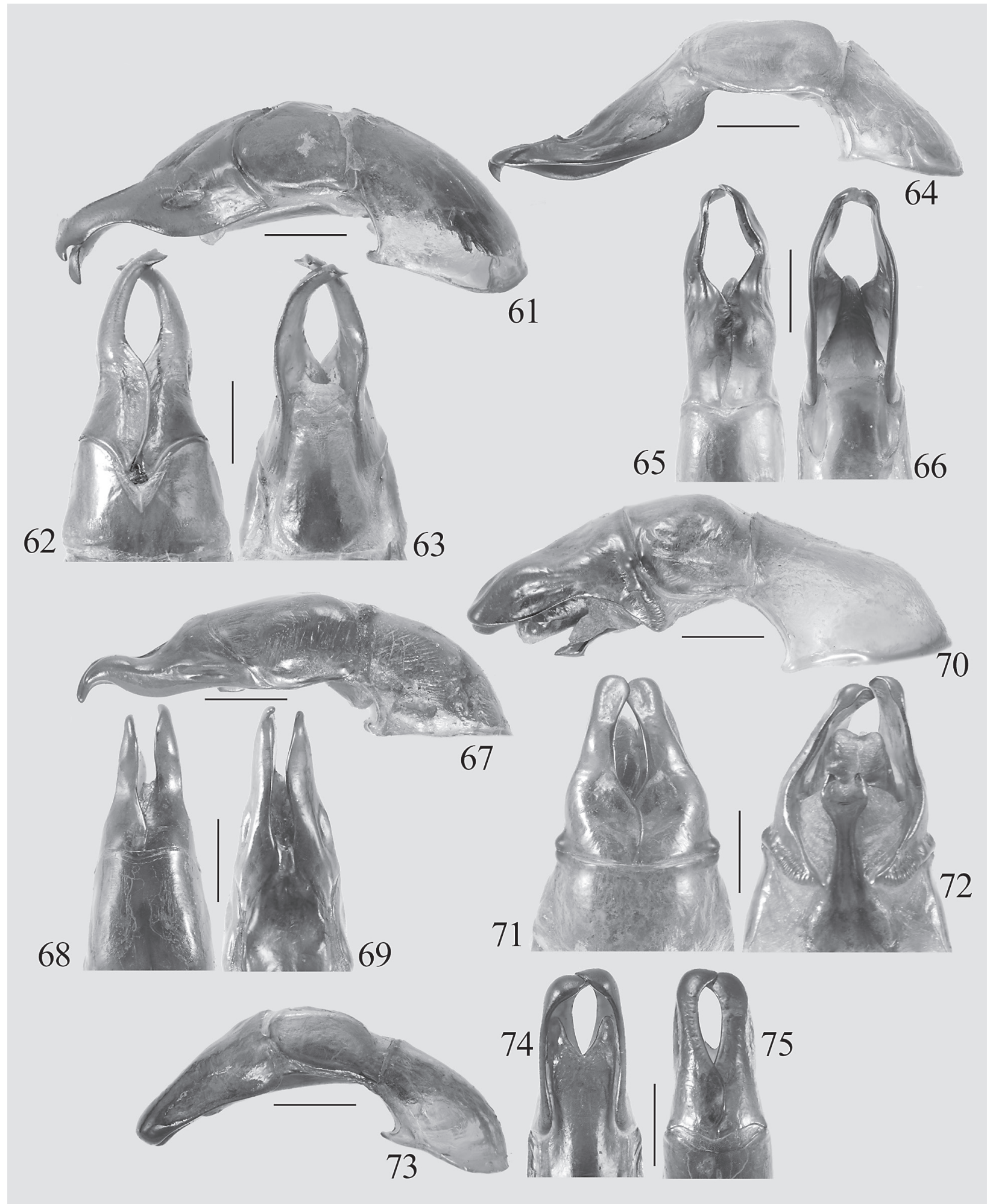

Figs 61-75: Mimela spp., aedeagi. - 61-63: M. plicatulla, China: Yunnan, Xishuanbanna (61 lateral view. 62 parameres, dorsal view. 63 parameres, ventral view). 64-66: M. linpingi, Thailand: Chiang Mai (64 lateral view. 65 parameres, dorsal view. 66 parameres, ventral view). 67-69: M. epipleurica, China: Yunnan, Tengchong (67 lateral view. 68 parameres, dorsal view. 69 parameres, ventral view). 70-72: M. laotina, Laos: Ban Phabat (70 lateral view. 71 parameres, dorsal view. 72 parameres, ventral view). 73-75: M. passerinii diana, China: Yunnan, Lufeng, Gaofeng (73 lateral view. 74 parameres, dorsal view. 75 parameres, ventral view). Scale bars: $1 \mathrm{~mm}$. 